\title{
First record of Vanessa braziliensis (Moore) (Lepidoptera: Nymphalidae) in Chile
}

\section{Primer registro de Vanessa braziliensis (Moore) (Lepidoptera: Nymphalidae) en Chile}

\author{
HÉCTOR A. VARGAS ${ }^{1 *}$ \\ ${ }^{1}$ Departamento de Recursos Ambientales, Facultad de Ciencias Agronómicas, Universidad de Tarapacá, Casilla 6-D, Arica, \\ Chile \\ *havargas@uta.cl
}

Vanessa Fabricius, 1807 is a cosmopolitan butterfly genus, with twenty one species described, ten of which are represented in the Neotropical Region (Lamas 2004, Wahlberg \& Rubinoff 2011). Two of these are currently known from Chile: Vanessa carye (Hübner, 1806) and Vanessa terpsichore Philippi, 1859 (Herrera et al. 1958, Field 1971).

Vanessa carye is a highly vagile butterfly (Walhberg \& Rubinoff 2011) whose geographic distribution includes many countries of South America and some oceanic islands: Easter Island, Juan Fernández Archipelago, and Tuamotu Archipelago (Field 1971). It is one of the more widely distributed butterflies in Chile, where may be found from the sea level to the highlands of the Andes (Herrera et al. 1958, Peña \& Ugarte 1996). Furthermore, due to its capacity for breeding on weedy and ornamental Malvaceae, it is one of the more frequently observed species in human-modified landscapes, and it is also one of the more familiar butterflies to non-entomologists in this country (Herrera 1987). By contrast, the geographic distribution of $V$. terpsichore is restricted to central-south Chile and southern Argentina (Herrera et al. 1958, Field 1971, Peña \& Ugarte 1996).

In January 2012, many Vanessa butterflies were observed flying around a group of Baccharis alnifolia (Asteraceae) shrubs, at about $3,300 \mathrm{~m}$ on the western slopes of the northern Chilean Andes, around Socoroma village, Parinacota Province (Fig. 2). Most of these butterflies were males and females of $V$. carye; however, one male of Vanessa braziliensis (Moore, 1883) was detected and caught. Subsequently, in January 2013, three females (Fig. $1 \mathrm{a}, 1 \mathrm{~b})$ of this species were collected in a location about five kilometers southwest of the collection site of the previous year. These butterflies were visiting small plants of Gnaphalium sp. (Asteraceae), where larvae were detected. The plants and the larvae were collected and brought to the laboratory into plastic vials, in order to rear them and confirm the host plant relationship. Fresh plant substrate was added periodically until last instar larvae completed feeding, with subsequent pupation and adult emergence.

Previous records of $V$. braziliensis are known from many other places in South America including the countries bordering Chile: Argentina, Peru and Bolivia (Field 1971). This is the first report of this butterfly from Chile. The absence of previous records from this territory is a curious fact, because many other butterflies have been successfully collected and studied here during the last century (e.g.: Herrera et al. 1958; Benyamini 1995, MacNiell 2002).

The host plant relationship here mentioned between Asteraceae and $V$. braziliensis agrees with previous records in the literature (Field 1971). Interestingly, the rearing records here documented demonstrate the adequacy of this geographic area for sustaining a local breeding population, dismissing the possibility of just some vagrant adult specimens. Moreover, this discovery raises the question about the origin of the north Chilean populations of $V$. braziliensis.

Some species of Vanessa are known for migratory behavior. At least two of these, i.e.: Vanessa atalanta (Linnaeus, 1758) and Vanessa cardui (Linnaeus, 1758), are powerful fliers and are able to move hundreds of kilometers (Stefanescu 1999, 2001). Migrations could be associated with sporadic range expansions, in which case northern Chile would be a fluctuating southern limit for the geographic distribution of $V$. braziliensis. Alternatively, this may be a permanent resident butterfly, but with too low population levels for easy detection; thus its discovery has been possible only after continuous field work.

Despite the small number of butterfly species expected in the arid landscapes of northern Chile, the discovery here reported together with other recent additions (e.g.: MacNeill 2002, Vargas \& Lamas 2011) suggest that some other butterflies may be waiting to be detected and studied. 




FIGURE 1. Female adult of Vanessa braziliensis; a) in dorsal view; b) in ventral view.

Figura 1. Hembra adulta de Vanessa braziliensis; a) en vista dorsal; b) en vista ventral.

Vouchers will be deposited in the Museo Nacional de Historia Natural de Santiago (MNNC), Santiago, Chile.

Material examined. CHILE, Parinacota. One male, Socoroma, Parinacota, Chile, January 2012, H.A. Vargas coll.; 1 male, 2 females (near) Socoroma, Parinacota, Chile, January 2013, H.A. Vargas coll.; 2 males, 2 females (near) Socoroma, Parinacota, Chile, February 2013, H.A. Vargas coll., reared from larva on Gnaphalium sp., January 2013 (Fig. 2).

\section{ACKNOWLEDGEMENTS}

The author would like to Felipe Méndez and José Storey for field assistance; to Jorge Macaya Berti, for identification of the host plant; to Mirna M. Casagrande, Olaf H.H. Mielke and Arthur M. Shapiro, for comments on a preliminary version of the manuscript; to Lafayette Eaton, for checking



Figure 2. Geographic position of the first record of Vanessa braziliensis in Socoroma, Parinacota, Chile.

Figure 2. Primer registro para Chile de Vanessa braziliensis en Socoroma, Parinacota.

the English version. This study was supported by project DGI 9710-13, Universidad de Tarapacá. Reinaldo Rivera provided the map.

\section{REFERENCES}

Benyamini, D. 1995. Synopsis of biological studies of the Chilean Polyommatini (Lepidoptera, Lycaenidae). Reports of the Museum of Natural History, University of Wisconsin, Stevens Point 52:1-51.

FIELD, W.D. 1971. Butterflies of the genus Vanessa and the resurrected genera Bassaris and Cynthia (Lepidoptera: Nymphalidae). Smithsonian Contributions to Zoology 84:1-105.

Herrera, J. 1987. Biología de Cynthia carye (Hübner, 1812), especie críptica de C. annabella Field, 1971 (Lepidoptera: Nymphalidae). Acta Entomológica Chilena 14:65-116.

Herrera, J., Etcheverry, M. \& Barrientos, R. 1958. Los Nymphalidae Chilenos. Anales de la Universidad de Chile 
116:237-268.

Lamas, G. 2004. Nymphalidae. Nymphalinae, pp. 249-257. In: Lamas, G. (Ed.), Checklist: Part 4A. Hesperioidea Papilionoidea. In: Heppner, J. B. (Ed.), Atlas of Neotropical Lepidoptera. Volume 5A. Gainesville, Association for Tropical Lepidoptera; Scientific Publishers, 474p.

MacNeill, C.D. 2002. Studies in the genus Hylephila Billberg, II. The boulleti species group (Hesperiidae: Hesperiinae). Journal of the Lepidopterists' Society 56:69-88.

Peña G., L.E. \& Ugarte P., A.J. 1996. Las mariposas de Chile. The butterflies of Chile. Santiago, Editorial Universitaria, $359 \mathrm{p}$.

Stefanescu, C. 1999. Migration patterns and feeding resources of the Painted Lady butterfly, Vanessa cardui (L.)
(Lepidoptera, Nymphalidae) in the northeast of the Iberian peninsula. Miscellània Zoològica 20:31-48.

Stefanescu, C. 2001. The nature of migration in the red admiral butterfly Vanessa atalanta: evidence from the population ecology in its southern range. Ecological Entomology 26:525-536.

Vargas, H.A. \& Lamas, G. 2011. First record of Phoebis argante chincha Lamas (Lepidoptera, Pieridae) in Chile. Revista Brasileira de Entomologia 55:445-446.

Wahlberg, N. \& Rubinoff, D. 2011. Vagility across Vanessa (Lepidoptera: Nymphalidae): mobility in butterfly species does not inhibit the formation and persistence of isolated taxa. Systematic Entomology 36:362-370.

Recibido: 05.06.13

Aceptado: 05.12.13 